\title{
Comment:
}

\section{IMPLIED WARRANTIES IN PATENT, KNOW-HOW AND TECHNICAL ASSISTANCE LICENSING AGREEMENTS}

"For historical reasons warranties have become identified primarily with transactions involving the sale or furnishing of tangible chattels ..., but they are not confined to such transactions." With that principle in mind, this Comment will investigate the circumstances under which warranties of merchantability and fitness for a particular purpose might be implied in patent, know-how and technical assistance licenses. ${ }^{2}$

While the issue of license warranties could arise in a number of contexts, a typical setting arises from the following transactions: $X$, an established manufacturer, invents a new type of widget and receives a patent for it. He grants to $Y$ an exclusive ${ }^{8}$ license to make and sell ${ }^{4}$ the new widget. The license contract ${ }^{5}$ also provides that $X$ will supply $Y$ with $X$ 's secret process which is necessary for the production of the new widgets. Moreover, the license provides that $X$ and his chief technician will be available to $Y$ at all reasonable times to advise and assist $Y$ in using the secret process to produce the new widgets. In return, $Y$ agrees to pay $X$ 10,000 dollars plus a royalty ${ }^{6}$ of five cents per widget manufactured, guaranteeing a minimum royalty of 200 dollars a month. ${ }^{7}$ If, after $Y$ has

1 Gagne v. Bertran, 43 Cal. 2d 481, 486, 275 P.2d 15, 19 (1954); see Booth S.S. Co. v. Meier \& Oelhaf Co., 262 F.2d 310 (2d Cir. 1958).

2 There are other types of licenses, but these are the major ones. See I. Ecrstrom, LICENSING IN Foreign Operations, at I.B.3 (1958).

3 By granting an exclusive license, the licensor, besides promising not to sue the licensee for infringement, also covenants not to license others to carry on and will not limself carry on the same commercial activities covered by the license. See Cutter Labs., Inc. v. LyophileCryochem Corp., 179 F.2d 80 (9th Cir. 1949). See also Mechanical Ice Tray Corp. v. General Motors Corp., 144 F.2d 720 (2d Cir. 1944); 4-One Box Mach. Makers v. Wirehounds Patents Co., $131 \mathrm{Me}$. 356, $163 \mathrm{~A} .167$ (1932). A nonexclusive license assures the licensee only that he will not be sued for infringing the patent under which he is licensed. See N.V. Phillips' Gloeilampenfabrieken v. Atomic Energy Comm'n, 316 F.2d 401, 409 (D.C. Cir. 1963).

4 A license can grant the licensee rights to make, use or sell an invention or process. It is possible to combine these rights, a very common license being one to make, use and sell. See, e.g., Federal Labs., Inc. v. Commissioner, 73 U.S.P.Q. 453 (T.C. 1947). Certain rights might be implied in the license. See Velsicol Chem. Corp. v. Hooker Clem. Corp., 230 F. Supp. 998, 1019 (N.D. Ill. 1964).

5 "Licenses lave no statutory basis, and rights under them arise from contract . . ." Farmland Irrigation Co. v. Dopplmaier, 48 Cal. 2d 208, 220, 308 P.2d 732, 739 (1957); accord, Baldwin Rubber Co. v. Paine \& Williams Co., 107 F.2d 350 (6th Cir. 1939).

6 "The term royalty ordinarily envisages a duty to make and a corresponding riglt to receive payments proportionate to the use of patented methods or machines." Eastman Oil Well Survey Corp. v. Lane-Wells Co., 21 Cal. 2d 872, 873, 136 P.2d 564, 565 (1943); see 2 A. WALKER, WALKER ON PATENTS $\S 413$ (2d ed. A. Deller 1965).

$\tau$ For examples of different royalty agreeements, sce Automatic Radio Mfg. Co, v. 
expended great sums of money to begin production of the new widgets, the entire endeavor is a failure-due either to a defect in the invention, the inapplicability of the secret production process to the new widget, or $X$ 's and his chief technician's general ineptness $-Y$ may claim a cause of action against $X$ which would relieve him of paying the minimum royalty, which would allow him to recover the 10,000 dollars he has already paid $X$, or which would compel $X$ to reimburse $Y$ for his reliance expenses and lost profits.

It is possible that $Y$ could obtain relief on a tort or contract theory such as fraud, negligent or innocent misrepresentation, or mistake of fact. However, this Comment will not consider these traditional bases of liability; instead it considers whether and under what circumstances $Y$ would have a cause of action agaimst $X$ for breach of an impled warranty of merchantability or fitness for a particular purpose. The absolute liability afforded by a warranty remedy would greatly aid a party in $Y$ 's position. It would obviate problems of proof and interpretation which are often encountered in fraud, misrepresentation and mistake of fact cases. Moreover, a warranty theory might provide a far greater range of recovery than the rescission or restitution remedy to which a plaintiff is often limited under other tort and contract avenues; ${ }^{8}$ for breach of warranty, he might be entitled to damages not only for amounts already paid under the contract but also for reliance and consequential losses. ${ }^{9}$

In considering the issue of implied warranties in licenses, there is an initial question of whether warranties should ever be implied in such contracts. It might be argued that if the parties to the hicense, which is generally a very complicated contract, have not included warranty protection, it is not within the courts' province to do so. ${ }^{10}$ Furthermore, because licenses generally involve new and unproved ideas, they are subject to greater elements of risk than are other contracts. Finally, it might be argued that because the parties to licenses are usually of equal skill and knowledge, they do not need implied warranty protection. However, each

Hazeltine Research, Inc., 339 U.S. 827 (1950) (royalties calculated on basis of total production even though licensor's patents not used); Kraus v. General Motors Corp., 120 F.2d 109 (2d Cir. 1941) ( $\$ .001$ per spark plug with guaranteed daily minimum). Licenses can also require fixed periodic payments irrespective of use. E.g., Bird's-Eye Veneer Co. v. Franck-Philipson \& Co., 259 F. 266 (6th Cir. 1918) ( $\$ 300$ per month). Licenses miglit also include royalty maximums. E.g., Tesra Co. v. Holland Furnace Co., 73 F.2d 553 (6th Cir. 1934) ( $\$ 1$ per machine until $\$ 50,000$ has been paid). See generally, L. Ecrstrom, supra note 2, at VIII.B.10.

8 See, e.g., Seneca Wire \& Mfg. Co. v. A.B. Leach \& Co., 247 N.Y. 1, 159 N.E. 700 (1928); G. Grtsmore, PrnNctples of the Law of Contracts § 119, at 171 (J. Murray ed. 1965); W. PROSSER, HandBoor of the LAW of TORTS 644-45, 703, 724-29 (3d ed. 1964) [hereinafter cited as W. Prosser, ToRTs].

${ }^{\circ}$ See text accompanying notes 165-73 infra.

10 Cf. Bird's-Eye Veneer Co. v. Franck-Philipson \& Co., 259 F. 266, 267-68 (6th Cir. 1918). 
of these arguments is applicable to transactions which have traditionally imported warranties. The fact that a detailed contract between parties of equal knowledge has a great element of risk should not of itself preclude the existence of an implied warranty. Certainly the fact that a contract involves elements of risk ${ }^{11}$ or has been negotiated between parties of substantially equal knowledge ${ }^{12}$ is important in any situation. But it should be remembered that

[a]n implied warranty is not one of the contractual elements of an agreement. It is not one of the essential elements to be stated in the contract nor does its application or effective existence rest or depend upon the affirmative intention of the parties. It is a child of the law. . . . Its origin and use are to promote high standards in business and to discourage sharp dealings. It rests upon the principle that "honesty is the best policy," and it contemplates business transactions in which both parties may profit..$^{13}$

In considering the many arguments for and against implying warranties in certain types of transactions, the courts have established various criteria for the existence of implied warranties in contracts and have excluded warranties from certain types of contracts. ${ }^{14}$ In this Comment the courts' considerations and conclusions as to what types of transactions should import warranties are used as the basis for determining whether and under what circumstances warranties should be implied in license agreements. Part I presents an analysis of cases in which licensed materials were alleged to be totally valueless or unsuited to the hicensee's needs. Part $\Pi$ of the Comment discusses various obstacles to finding imphied warranties in license agreements: For example, a hicense is technically not a sale, ${ }^{15}$ and courts have often asserted that a sale is a prerequisite to an implied warranty; ${ }^{16}$ also, because a licensee and licensor are frequently of equal skill and knowledge, special attention is given to the warranty requirements of inspection and rehance. Parts III, IV and V discuss the application of implied warranty law to patent, know-how and technical assistance licenses. A short examination of damages which would be awarded for breach of a license warranty is presented in Part VI.

11 See text accompanying notes 90-92, 121-24 infra.

12 See text accompanying notes 76-78, 86-89 infra.

18 Bekkevold v. Potts, 173 Minn. 87, 89, 216 N.W. 790, 791 (1927); see Vlases v. Montgomery Ward \& Co., 377 F.2d 846, 849 (3d Cir. 1967).

14 See text accompanying notes $43,56-59$ infra.

15 See text accompanying notes 32-35 infra.

16 See, e.g., Amacorp Indus. Leasing Co. v. Robert C. Young Associates, Inc., $237 \mathrm{Cal}$. App. 2d 724, 728, 47 Cal. Rptr. 294, 297 (1965); Lawson v. Rusconi, 112 Cal, App. 366, 368,296 P. 628,630 (1931). 


\section{I}

PRIOR IICENSE CASES

Courts which have been faced with a patent or know-how ${ }^{17}$ license which was either useless or unsuited for the licensee's particular purpose have generally granted the hicensee relief only on the theory that there was a lack of consideration; ${ }^{18}$ very few cases have proceeded on the breach of an implied warranty theory. ${ }^{10}$

\section{A. Lack of Consideration Theory}

Generally, if the licensed patent or know-how is worthless, the licensee is allowed to avoid the contract. ${ }^{20}$ This result is manifest where the only consideration required of the licensee is a royalty which is directly proportionate to profits from sales; however, a licensee must depend on judicial relief to recover a base payment or to be released from the duty of paying fixed periodic payments or minimum royalties.

Many cases have held the licensees to their contract because the licensees bargained for no more than the right to develop an imperfect idea ${ }^{21}$ or the chance that an invention might become profitable. ${ }^{22}$ In such cases the hicensees' expectations have been fulfilled.

In patent license cases the courts have considered an additional factor and have often held the licensees to their contracts. The fact that a

17 Technical assistance licenses are not considered in this part. See text accompanying notes 149-64 infra.

18 E.g., Emerson Elec. Mfg. Co. v. Printed Motors, Inc., 252 N.Y.S.2d 600 (Sup. Ct. 1964); Penn v. Garabed Gulbenkian, 243 S.W.2d 220, 223 (Tex. Civ. App. 1951), aff'd, 151 Tex. 412, 252 S.W.2d 929 (1952).

19 E.g., General Talking Pictures Corp. v. Shea, 187 Ark. 568, 61 S.W.2d 430 (1933); Bobrick Chem. Co. v. Prest-O-Lite Co., 160 Cal. 209, 116 P. 747 (1911); Nettograph Mach. Co. v. Brown, 28 Okla. 436, 114 P. 1102 (1911); Hartford Battery Sales Corp. v. Price, 119 Pa. Super. 165, 181 A. 95 (1935).

At least two cases have explicitiy reserved judgment as to whether there could be warranty liability under licenses. In both cases the courts did point out that the facts would not have justified warranty liability if, in fact, it would be a proper remedy. Bird's-Eye Veneer Co. v. Franck-Philipson \& Co., 259 F. 266 (6th Cir. 1918), discussed in note 132 infra; Lawson v. Rusconi, 112 Cal. App. 366, 296 P. 628 (1931), discussed in text accompanying notes 108-09 infra.

20 E.g., Meissner v. Standard Ry. Equip. Co., 211 Mo. 112, 109 S.W. 730 (1908); Nettograph Mach. Co. v. Brown, 28 Okla. 436, 114 P. 1102 (1911); Penn v. Garabed Gulbenkian, 243 S.W.2d 220 (Tex. Civ. App. 1951), aff'd, 151 Tex. 412, 252 S.W.2d 929 (1952).

21 E.g., Appliance Corp. v. Speed Queen Corp., 186 F.2d 798 (7th Cir. 1951), discussed in note 132 infra.

22 E.g., Harris v. United Automatic Cigarette Co., 114 Cal. App. 583, 300 P. 71 (1931); Emerson Elec. Mfg. Co. v. Printed Motors Inc., 141 U.S.P.Q. 68, 252 N.YS.2d 600 (Sup. Ct. 1964). 
licensee has received the right to operate under a legally protected patent is itself a form of consideration; and so long as the patent represents some, albeit very little, usefulness, the licensee has received rights from the licensor which constitute a legally valuable consideration. ${ }^{23}$ These decisions seem unreasonably narrow in their approach to the issues presented. The patent licensee bargains not only for the right to act without fear of suit for infringement, but also, and more important, for the right to exploit the process or product covered by the patent. Thus it is the information and ideas for which a patent licensee, much like a know-how hicensee, ${ }^{24}$ bargains. The license provision which assures the licensee that he will not be sued for infringement is only one of the aspects of the agreement. If the information and ideas are useless or unsuited to the licensee's purposes, it cannot be said that the right to use them was valuable. The better reasoned cases have recognized that a licensed product or process inust be marketable or commercially exploitable for the licensor to hold the licensee to his contract. ${ }^{25}$

\section{B. Implied Warranty Theory}

The license cases which have considered a breach of warranty theory are few. Those cases granting the licensee warranty relief have all involved licenses to use or sell products which were manufactured by the licensor. The licensee did not receive the right to make a product pursuant to licensed plans or inventions; rather, the licensee, much like the average bailee or purchaser, has simply received a finished product in a trans-

23 E.g., Van Norman v. Barbeau, 54 Minn. 388, 55 N.W. 1112 (1893) (criticized in note 132 infra). In Bird's-Eye Veneer Co. v. Franck-Philipson \& Co., 259 F. 266, 269 (6th Cir. 1918), it was stated that there is a "well-known distinction between that lack of patentable utility which makes a patent void and that lack of commercial utility which makes its exploitation not profitable until sufficient capital and skill are employed, or until market conditions are favorable, or until some improvements and refinements are discovered." Cf. R. ELIIs, Patent Licenses \& 323 (3d ed. A. Deller 1958) [hereinafter cited as R. Euris, Patent Licenses]. Bat see note 132 infra; text accompanying note 120 infra.

24 The fact that a patent licensor bas received letters patent and has thereby publicized his invention should not cloud the issue of what it is that he gives the licensee. If there were no patent laws, the licensor would keep his invention secret and the licensee would bargain for the same invention under the name of "know-how." The practical effect of both know-how and patent licenses is that licensees receive valuable knowledge which they otherwise would not have or could not legally use.

25 E.g., Stentor Elec. Mfg. Co. v. Klaxon Co., 115 F.2d 268, 272 (3d Cir. 1940), aff'd on rehearing, 125 F.2d 820 (1940), rev'd on other grounds, 313 U.S. 487 (1941); Meissner v. Standard Ry. Equip. Co., 211 Mo. 112, 109 S.W. 730 (1908); Sainderichin v. Gabrilovitch, 274 App. Div. 100, 79 N.Y.S.2d 726 (1948); Penn v. Garabed Gulbenkian, 243 S.W.2d 220 (Tex. Civ. App. 1951), aff'd, 151 Tex. 412, 252 S.W.2d 929 (1952); Herman v. Gray, 79 Wis. 182, 48 N.W. 113 (1891); cf. Bobrick Chem. Co. v. Prest-O-Lite Co., 160 Cal. 209, 116 P. 747 (1911). 
action which was tantamount to a lease ${ }^{26}$ or sale. ${ }^{27}$ Consequently, these cases involved the application of implied warranty law to the basic types of commercial transactions to which such theories have traditionally been applied.

It miglit be concluded from these cases and from the fact that no court has ever held that plans and inventions are warranted, that warranties will not be imphed where only information, plans and ideas are exchanged. Such a conclusion must rest on the premise that a finished product is, for the purposes of implied warranty law, significantly different from the information, ideas or plans which are used to make the product. Arguably, one such difference is that the characterization that plans and ideas represent the product of men's judgment and services whicli are only rarely warranted. ${ }^{28}$ Such an argnment overlooks two important factors: First, goods to which implied warranty law has consistently been applied are obviously the products of men's services and judgments. Second, a licensor has had an opportunity to scrutinize and evaluate the effectiveness, suitability and usefuhress of his product before he licenses them. A soil analyst, civil engmeer or doctor, on the other hand, is presented with a unique fact situation when asked to provide his services and judgment; unlike the hicensor, he cannot experiment so as to insure that his analysis that the ground will not give way when a large building is placed upon it, his plans for draining a yet unbuilt subdivision, or his diagnosis that an operation is necessary is correct. If he errs, he cannot change his prior actions because loss will already have been sustained. On the other hand, a licensor, much like a manufacturer, can use, refine and evaluate his plans and invention to insure that, before they are licensed, they are capable of mastering the task for which they are to be used.

Therefore, it should not be concluded that warranties will be implied only when the product accompanies an invention or plan and not when the invention or plan alone is exclianged, for there is no significant difference between the two transactions for the purposes of warranty law. If a licensor himself makes a device pursuant to his invention and licenses another to use or sell the device, and the device is defective due to the invention's failure, the licensee has an impled warranty remedy; ${ }^{29}$ it would be incongruous to deny the licensee the same remedy simply be-

26 E.g., Milwaukee Tank Works v. Metals Coating Co. of America, 196 Wis. 191, 218 N.W. 835 (1928).

$2 \pi$ E.g., Nettograph Mach. Co. v. Brown, 28 Okla. 436, 114 P. 1102 (1911).

28 See, e.g., Pepsi Cola Bottling Co. v. Superior Burner Serv. Co., 427 P.2d 833 (Alas. 1967); note 43 infra and accompanying text.

29 Cases cited notes $26-27$ supra. 
cause he has made exactly the same defective device in conformance with the same invention..$^{30}$

\section{II}

\section{GENERAL OBSTACLES TO IMPLYING WARRANTIES IN LICENSES}

\section{A. Necessity of a Sale}

Courts frequently indicate that a "sale" is a prerequisite to the existence of an implied warranty. ${ }^{31}$ However, even though a license might be "more closely assimilated to a sale calling for delivery and payment in installments than to anything else," as having made a purchase, ${ }^{33}$ a hicense is nonetheless not a sale since the licensor retaims title to the know-how or patent. ${ }^{34}$ Moreover, in the case of nonexclusive licenses, no property rights are exchanged. ${ }^{35}$

However, the fact that a license is technically not a sale should not preclude implied warranties. What a hicensee receives is the valuable right and requisite knowledge to do freely that which he would otherwise be unable to do $^{36}$ Licensed information, ideas and advice are certainly as valuable to the hicensee as are purchased products to the buyer ${ }^{37}$ Furthermore, the licensor-licensee relationship, like that of the seller and buyer, is based on the contract from which the rights of the parties arise. ${ }^{88}$ Differences in contract form and in labels should not affect the parties' rights when the contracts serve essentially equivalent purposes. These considerations justify affording the licensee the legal remedies afforded the buyer.

${ }^{30}$ Cf. MacKnight Flintic Stone Co. v. Mayor of New York, 160 N.Y. 72, 83, 54 N.E. 661, 664 (1899); cases cited notes 40-41, 84-85 infra.

31 E.g., Amacorp Indus. Leasing Co. v. Robert C. Young Associates, Inc., 237 Cal. App. 2d 724, 728, 47 Cal. Rptr. 294, 297 (1965) ("implied warranties arise only when there is a sale or a contract of sale").

32 National Foam Sys., Inc. v. Urquhart, 103 F. Supp. 433, 435 (E.D. Pa. 1952).

33 Bird's-Eye Vencer Co. v. Franck-Philipson \& Co., 259 P. 266, 269 (6th Cir. 1918); Wyman v. Monolith Portland Cement Co., 3 Cal. App. 2d 540, 544, 39 P.2d 510, 511 (1935) (characterizing the transaction as a "sale of certain rights or licenses").

34 See Henry v. A.B. Dick Co., 224 U.S. 1, 24 (1912); 4 A. WALKER, supra note 6, § 343, at 377 .

${ }^{35}$ See N.V. Phillips' Gloeilampenfabricken v. Atornic Energy Comm'n, 316 F.2d 401, 409 (D.C. Cir. 1963). An exclusive licensee probably does have a property intercst in the patent or know-how since he, unlike a non-exclusive licensee, can initiate actions against infringers, R. EurIS, PATENT LICENSES, supra note 23 , at $\$ \$ 381-90$, including the licensor himself, Cutter Labs., Inc. v. Lyophile-Cryochem Corp., 179 F.2d 80, 93 (9th Cir. 1949). It would therefore seem that the exclusive licensce has the right to possess and use the patent to the exclusion of others, or lás property. CAI. Crv. CODE $\S 654$ (West 1954).

36 See U.S. Indus., Inc. v. Otis Eng'r Corp., 277 F.2d 282, 291 (5th Cir. 1960).

37 See Henry v. A.B. Dick Co., 224 U.S. 1, 24 (1912).

38 Cf. Simpson v. Powered Prods., Inc., 24 Conn. Supp. 409, 411-12, 192 A.2d 555, 557 (CP. 1963). 
The foregoing argument is buttressed by the fact that courts frequently hold that there are implied warranties in nonsales transactions, ${ }^{39}$ many of which are closely analogous to hicenses. Persons who supply plans and specifications to a contractor impliedly warrant their correctness and will be liable for all damages suffered by the contractor due to the plans' or specifications' maccuracies. ${ }^{40}$ A contractor, in turn, warrants that the structure he builds "will be fit for its intended use both as to workmanship and materials," ${ }^{41}$ even though a contract for workmanship and materials is not a "sale." 42 In both of the above cases the plans and specifications which the contractor uses are not sold and yet, if they are defective, the party supplying the plans can be held to warranty liability.

Service contracts, on the other hand, normally convey no warranties. It is "the general rule ... that those who sell their services for the guidance of others in their economic, financial and personal affairs are not liable in the absence of negligence or intentional misconduct. ${ }^{243}$ This rule is especially significant for technical assistance licenses because they are essentially service contracts; however, while this rule represents one case of not implying warranties in nonsales ${ }^{44}$ transactions, it does not necessarily affect patent and know-liow licenses. ${ }^{45}$

89 Note, Extension of Warranty Concept to Service-Sales Contracts, 31 IND. L.J. 367 (1956); Note, Should the Doctrine of Implied Warranties Be Limited to Sales Transactions?, 2 VAND. I. REV. 675 (1949).

40 E.g., United States v. Spearin, 248 U.S. 132 (1918); Montrose Contracting Co. v. County of Westchester, 80 F.2d 841 (2d Cir. 1936); Penn Bridge Co. v. City of New Orleans, 222 F. 737 (5th Cir. 1915); Souza \& McCue Constr. Co. v. Superior Court, 57 Cal. 2d 508, 370 P.2d 338, 20 Cal. Rptr. 634 (1962); Wunderlich v. State, 241 A.C.A. 58, 151 Cal. Rptr. 151 (1966), rev'd on other grounds, 65 Cal. 2d 777, 423 P.2d 545, 56 Cal. Rptr. 473 (1967).

41 Aced v. Hobbs-Sesack Plumbing Co., 55 Cal. 2d 573, 582, 360 P.2d 897, 902, 12 Cal. Rptr. 257, 262 (1961); accord, Kuitems v. Coveil, 104 Cal. App. 2d 482, 231 P.2d 552 (1951); Mulhern v. Hederich, 430 P.2d 469 (Colo. 1967); Robertson Lumber Co. v. Stephen Farmers Co-op. Elevator Co, 274 Minn. 17, 143 N.W.2d 622 (1966); Econonyy Fuse \& Mfg. Co. v. Raymond Concrete Pile Co., 111 F.2d 875 (7th Cir. 1940); Torrance v. Durisol, 20 Conn. Supp. 62, 122 A.2d 589 (Super. Ct. 1956); see Fossum v. Timber Structures, Inc., 54 Wash. 2d 317, 341 P.2d 157 (1959).

42 Aced v. Hobbs-Sesack Plumibing Co., 55 Cal. 2d 573, 580, 360 P.2d 897, 901, 12 Cal. Rptr. 257, 261 (1961); accord, Robertson Lumber Co. v. Stephen Farmers Co-op. Elevator Co., 274 Minn. 17, 143 N.W.2d 622 (1966).

43 Gagne v. Bertran, 43 Cal. 2d 481, 487; 275 P.2d 15, 20 (1954) (soil analyst); accord, Pepsi Cola Bottling Co. v. Superior Burner Serv. Co., 427 P.2d 833 (Alas. 1967) (boiler repairman); Bonadiman-McCain, Inc. v. Snow, 183 Cal. App. 2d 58, 6 Cal. Rptr. 52 (1960) (civil engineer); Aegis Prods., Inc. v. Arriflex Corp. of America, 25 App. Div. 2d 639, 268 N.Y.S.2d 185 (1966) (camera repairman); see Sloneker v. St. Joseph's Hosp., 233 F. Supp. 105 (D. Colo. 1964) (lospital services), noted in 18 OkrA. L. REv, 104 (1965). Contra, Broyles v. Brown Eng'r Co., 275 Ala. 35, 151 So. 2d 767 (1963) (civil engineer).

44 But notice that the court speaks of "those who sell their services." Gagne v. Bertran, 43 Cal. 2d 481, 487, 275 P.2d 15, 20 (1954) (empliasis added).

45 See text accompanying notes $155-64$ infra. 
Bailments are closely analogous to licenses because in both transactions title remains in the supplier..$^{48}$ At the same time, however, it should be noted that a license is often more like a sale than is a bailment because a patent license often extends for the full, unexpired life of the patent ${ }^{47}$ and a know-how license is frequently designed for an indefinite period. Therefore, whereas a bailee is required to return the bailed property, ${ }^{48}$ a licensee is often assured that he will be able to use the licensed material forever. ${ }^{40}$

Many courts have nonetheless implied warranties in bailments, ${ }^{60}$ generally using the criteria of sales law. ${ }^{51}$ The factors which appear to have been most persuasive to these courts, and which are often applicable to licenses, are that a bailor is mucl more knowledgeable of the bailed property than is the bailee, ${ }^{52}$ that bailments often accomplish the same commercial ends as do sales, ${ }^{53}$ and that bailments demand the same ligh degree of integrity and fairness as are demanded in sales. ${ }^{54}$ Because a bailor relets the very same product many times and therefore has generally had more opportunity to evaluate the performance of each product than has a seller

46 See CAT. CIv. Code § 1926 (West 1954); 4 A. WALKER, supra note 6, \& 343, at 377.

47 See, e.g., Maguire Indus., Inc. v. Harrington \& Richardson Arms Co., 79 F. Supp. 81

(D. Mass. 1948); see also Brulotte v. Thys Co., 379 U.S. 29 (1964).

48 See Thomson Spot Welder Co. v. Dickelman Mfg. Co., 15 Ohio App. 270, 274 (1921);

Cax. Civ. Code $\$ 1925$ (West 1954).

49 After seventeen years the patented invention is public property. Brulotte v. Thys Co., 379 U.S. 29, 31 (1964). If at any time a trade secret loses its secrecy, it likewise becomes a matter of public property. Reynolds Metals Co. v. Skinner, 166 F.2d 66 (6th Cir.), cert. denied, 334 U.S. 858 (1948); Hooker Chem. Corp. v. Velsicol Chem. Corp., 235 F. Supp. 412 (W.D. Tenn: 1964); National Rejectors, Inc. v. Trieman, 409 S.W.2d 1 (Mo. 1966); Car.

Civ. Code \& 983(b) (West 1954); Restatenent of TORTS \& 757, comment b at 6 (1939).

${ }^{50}$ See, e.g., Marcos v. Texas Co., 75 Ariz. 45, 251 P.2d 647 (1952); General Talking Pictures Corp. v. Shea, 187 Ark. 868, 61 S.W.2d 430 (1933); Thompson Lumber Co. v. Cozier Container Corp., 80 Idaho 455, 333 P.2d 1004 (1958); In re Casualty Co., 250 N.Y. 410, 165 N.E. 829 (1929); Tully v. Empire Equip. Corp., 282 N.Y.S.2d 322 (App. Div. 1967); Milwaukee Tank Works v. Metals Coating Co. of America, 196 Wis. 191, 218 N.W. 835 (1928); Annot., 68 A.L.R.2d 850 (1959); W. Prosser, supra note 8, at 655-66; 9 S. WIILISTon, Contracts $\$ 1041$, at 919-21 (3d ed. W. Jaeger 1967); Note, 31 Ind. L.J. 367, 371-72 (1956); Note, 2 VAND. L. REv. 675, 677-79 (1949); see also Bochck Constr. Equip. Corp. v. H. Fuller \& Sons, Inc., 19 Wis. 2d 658, 121 N.W.2d 303 (1963).

By $\S 8(2)$ of the English Hire-Purchase Act, 1938, 1 \& 2 Geo, 6, as amended, HirePurchase Act, 1964, c. 53, §12(2), the hirer receives greater warranty protection than does the purchaser. See Goode, Htre-Purchase Law \& Prictice 108 (1962); id. 31-32 (Supp. 1964); see also J. Flemmig, Torts 475-76 (3d ed. 1965).

51 See, e.g., Demos Constr. Co. v. Service Supply Corp., 153 Pa. Super. 623, 34 A.2d 828 (1943); Hatten Mach. Co. v. Bruch, 59 Wash. 2d 757, 370 P.2d 600 (1962).

52 E.g., Booth S.S. Co. v. Meier \& Oelhaf Co., 262 F.2d 310, 314 (2d Cir. 1958); Cintrone v. Hertz Truck Leasing \& Rental Serv., 45 N.J. 434, 446, 450-51, 212 A.2d 769, 775, 778 (1965), noted in 20 ART. L. REv. 175 (1966).

53 E.g., Cintrone v. Hertz Truck Leasing \& Rental Serv., 45 N.J. 434, 447, 212 A.2d 769, 776 (1965); Thomson Spot Welder Co. v. Dickelman Mfg. Co., 15 Ohio App. 270, 274 (1921).

54 See Thomson Spot Welder Co. v. Dickelman Mfg. Co., 15 Ohio App. 270, 274 (1921). 
who simply receives and immediately sells a particular product, perhaps warranties should more readily be found in bailments than in sales. Indeed, one court has stated that what is true of implied warranties in sales "applies with equal force, if not with stronger reason, to the case of a lease of goods for a particular purpose."

In California it was the law that a bailor "imphedly warrants only that he has exercised reasonable care to ascertain that the chattel is safe and suitable for the purpose for which it is hired," and this "does not make lim an insurer .... ".68 Consequently, even though this statement might connote a form of warranty liability, it is essentially a negligence standard. ${ }^{57} \mathrm{How}$ ever, a court of appeal has recently reviewed California and other states' decisions in nonsales cases and concluded that "the iniplied warranties which are apphicable in bailment contracts are analogous to those applicable in sale transactions . . . " "58 This indicates that California is likely to follow the majority of courts and hold bailors to the absolute liability of warranty.

Other courts, however, have rejected all notions of imphed warranty liability in bailments and simply hold the bailor to a standard of reasonable care. .9 These courts may adhere to their decisions in the area of bailments, however, without necessarily precluding warranty liability from licensing

\footnotetext{
55 Hartford Battery Sales Corp. v. Price, 119 Pa. Super. 165, 171, 181 A. 95, 98 (1935).

50 McNeal v. Greenberg, 40 Cal. 2d 740, 742, 255 P.2d 810, 812 (1953); accord, Zucker v. Passetti Trucking Co., 191 Cal. App. 2d 260, 12 Cal. Rptr. 692 (1961); Tierstein v. Licht, 174 Cal. App. 2d 835, 345 P.2d 341 (1959); Kite v. Coastal Oil Co., 162 Cal. App. 2d 336, 328 P.2d 45 (1958); Sproul v. Cuddy, 131 Cal. App. 2d 85, 280 P.2d 158 (1955).

57 Although some of these cases have been cited as implied warranty cases, e.g., Farnsworth, Implied Warranties in Non-Sales Cases, 57 CoLur. L. Rev. 653, 656 (1957), the issue is clearly one of negligence. See Tierstein v. Licht, 174 Cal. App. 2d 835, 345 P.2d 341 (1959) ; Prosser, Strict Liability to the Consumer in California, 18 Hastrnas L.J. 9, 27-28 (1966). The confusion among the cases and interpretations thereof has been noted elsewhere. See W. Prosser, supra note 8, at 655; Note, 31 IND. L.J. 367, 372 n.25 (1956); Note, 2 VAND L. REv. 675, 677-78 (1949).

58 Holmes Packaging Mach. Corp. v. Bingham, 252 A.C.A. 926, 937, 60 Cal. Rptr. 769, 775 (1967); cf. Martinez v. Nichols Conveyor \& Eng'r Co., 243 Cal. App. 2d 795, 799, 52 Cal. Rptr. 842, 844 (1966). The Holmes decision explicitly rejected the theory that warranty liability could be based on Civil Code $\S 1955$ (West 1954). That section provides: "One who lets personal property must ... put it into a condition fit for the purpose for which he lets it ...." Rather, the Holmes court relied on cases in which warranties have been implied notwithstanding there were no sales. 252 A.C.A. at 934-35, 60 Cal. Rptr. at 774-75.

50 See, e.g., Fort Pierce Gas Co. v. Toombs, 193 So. 2d 669 (Fla. App. 1966); Brookshire v. Florida Bendix Co., 153 So. 2d 55 (Fla. App. 1963), appeal dismissed, 163 So. 2d 881 (Fla. 1964); Annot., 68 A.L.R.2d 850 (1959); cf. Redmon v. U-Hall Co., 210 Tenn. 262 , 358 S.W.2d 300 (1962) (no implied warranty that van, subject to bailee's inspection, would not leak).
} 
agreements. The preference given negligence liability, and the consequent lesser burden on bailors as compared to sellers, might be explained on two grounds. ${ }^{60}$ First, the bailor does not have continuing control of his property and cannot be expected to know whether it was damaged while in the control of a prior bailee. ${ }^{61}$ This factor, lowever, is clearly inapposite to licenses since a licensor's ideas, plans and information cannot be "damaged" by a prior licensee. A second explanation of the preference for negligence liability might be that the consideration which a single bailee gives for the limited use of a product is appreciably less than that given by a buyer of the same product. It would be unreasonable to hold the bailor to absolute warranty liability since the consideration he receives is not commensurate with the risk. ${ }^{62}$ Again, this produces a significant difference between the bailment and the license: If the licensor grants an exclusive license, he will receive the same consideration as if he had made an assignment; ${ }^{63}$ in fact, many exclusive licenses are held to be assignments. ${ }^{64}$ If the licensor grants

${ }^{60}$ The cases do not articulate the reason for the preferred treatment accorded bailors. The two reasons suggested here are believed inadequate and their shortcomings are noted in the following two footnotes.

61 Quaere whether a bailor of a new, unused product would be held to impliedly warrant its merchantability or fitness. Furthermore, the significance of prior use is greatly diluted in light of many cases which have held sellers of used goods to warranty hability. See, e.g., Standard Brands Inc. v. Consolidated Badger Co-op., 89 F. Supp. 5 (E.D. Wis. 1950) ; Lindberg v. Coutches, 167 Cal. App. 2d Supp. 828, 334 P.2d 701 (Super. Ct. 1959); Drumar Mining Co. v. Morris Ravine Mining Co, 33 Cal. App. 2d 492, 92 P.2d 424 (1939); Enix v. Diamond T. Sales \& Serv. Co., 188 So. 2d 48 (Fla. App. 1966) (dictum); Kaufman v. Katz, 356 Mich. 354, 97 N.W.2d 56 (1959); 1 S. Wrisiston, The LAw GovERNING SALES of Goods § 232, at 594-95 (rev. ed. 1948) [hereinafter cited as WIIISTON, Sales]. But see Intrastate Credit Serv., Inc. v. Pervo Paint Co., 236 Cal. App. 2d 547, 553, 46 Cal. Rptr. 182, 185 (1965) (general rule of no warranty when used goods are subject to inspection); Keating v. DeArment, 193 So. 2d 694 (Fla. App. 1967) (usually no warranty in sale of used goods, one judge disagreeing on this point).

62 See Redmon v. U-Haul Co., 210 Tenn. 262, 358 S.W.2d 300 (1962) (warranty that leased van is waterproof is matter to be negotiated); of. Gagne v. Bertran, 43 Cal. $2 \mathrm{~d} 481$, 487, 275 P.2d 15, 19-20 (1954) (service contract; "his fee and the fact that he was paid by the hour . . . indicate he was selling service and not insurance"). The cogency of the argument can be challenged on three grounds: First, the lease often accomplishes the same purposes as the sale. Second, in the aggregate the consideration received from any single product can reasonably be expected to bring the bailor a profit comparable to that of the seller. Third, the bailor could adjust his rates as the seller was forced to increase his prices to reflect the warranty obligation imposed upon him.

63 A licensor and his licensee might prefer the license for tax purposes and the license can be designed to have the same effect as an installnent salc. See text accompanying note 32. supra.

04 If a licensor transfers an exclusive license to make, use and sell without restriction, the agreement is tantamount to a sale and will be so considered. See, e.g., Bloch v. Umited States, 102 F. Supp. 457 (S.D.N.Y. 1951). But if the license substantially restricts the licensee's rights in any respect, it will be considered a bicense. Compare All Steel Engines, Inc. v. Taylor Engines, Inc., 88 F. Supp. 745 (N.D. Cal. 1950), with Maguire Indus., Inc. 
many nonexclusive licenses, then, unlike the bailor, he can realize greater rewards for his single product because lie might have many licenses outstanding for the same know-how, patent or technical assistance at the same time. In addition, as licenses are generally given for longer periods than bailments, the consideration more closely compares to that given for sales. ${ }^{65}$ Therefore, imphed warranty liability might be found even in those jurisdictions which recognize only negligence liabihty in bailments.

In summary, there is no valid reason to deny the existence of implied warranties in licenses simply because they are not sales. Licenses are substantially like sales. Moreover, licenses are closely analogous to nonsales transactions in which the courts have found warranties.

\section{B. Possibility for Examination}

It had been a general rule in the law of sales ${ }^{66}$ that wlien a consumer either examined ${ }^{67}$ a product or had the opportunity to do so the supplier was not liable on a theory of implied warranty for losses due to defects which the consumer ought to have ascertained on examination. ${ }^{68}$ The Uniform Commercial Code rejects this standard and imposes liability only if the consumer has "refused to examine" after the supplier has made "a demand ... that the [consuner] examine the goods fully."70 In this way the supplier puts the consumer on notice that the latter assumes the risk of defects ascertainable on examination. ${ }^{71}$

The possibility of exculpation from warranty liability due to inspection

v. Harrington \& Richardson Arms Co., 79 F. Supp. 81 (D. Mass. 1948). See generally Bell Intercontinental Corp. v. United States, 381 F.2d 1004 (Ct. Cl. 1967).

05 Bailments are usually for a day or week, although many are for longer periods; licenses are almost always for a period of years.

08 Throughout this Comment the requirements of the law of sales warranties will be used as applicable to licenses. These requirements are commonly used in other nonsales transactions. See, e.g., Robertson Lumber Co. v. Stephen Farmers Co-op. Elevator Co., 274 Minn. 17, 143 N.W.2d 622 (1966) (construction contract); Hatten Mach. Co. v. Bruch, 59 Wash. 2d 757, 370 P.2d 600 (1962) (chattel lease); 9 S. Wrirston, Contracts § 1041, at 919-21 (3d ed. W. Jaeger 1967).

87 The Uniform Commercial Code $\S 2-316(3)(b)$ and Uniform Sales Act $\S 15(3)$ use the word "examine" although the courts and authorities generally refer to "inspection." See, e.g., Electric Advertising, Inc. v. Sakato, 94 Ariz. 68, 381 P.2d 755 (1963); Intrastate Credit Serv., Inc. v. Pervo Paint Co., 236 Cal. App. 2d 547, 46 Cal. Rptr. 182 (1965); L. Vold, Handbook of the Law of Sales 436 (2d ed. 1959); 1 Wintiston, Sales § 234. But cf. UnIForar Contarercial CODE \$ 2-316, Comment 8. The terms will be used interchangeably in this Comment.

${ }^{68}$ E.g., Marcos v. Texas Co., 75 Ariz. 45, 251 P.2d 647 (1952); McCormick v. Hoyt, 53 Wash. 2d 338, 333 P.2d 639 (1959); see 1 Williston, SAces \& 234; L. Vold, supra note 67 , at 436 .

69 Untrorar Comarerctal Code $\S 2-316(3)$ (b).

$70 I d$. § 2-316, Comment 8.

71 Id. 
is especially important in license cases for two reasons: First, the licensee will often possess sufficient knowledge to understand and evaluate the material to be licensed. Unlike the average purchaser of an automobile, for example, whose inspection would not constitute a waiver of warranty because he has inadequate knowledge, the hicensee will more often be able to make a meaningful inspection. ${ }^{72}$ Second, the plans, information and ideas which are licensed are likely to be more important to a licensee than are goods to the average purchaser, and the licensee will probably be more anxious to inspect thoroughly the material to be licensed.

On the other hand, due to the complicated nature of patents, know-how and technical assistance, a licensee who has examined the subject matter of the license could still have a warranty remedy. If reasonable inspection before completion of the negotiations for the license is impossible or impracticable, even though the licensee has the knowledge necessary to undertake a ineamingful inspection, such inspection is not required. ${ }^{73}$ This is not to say that inspection need not be made because it would involve labor or inconvemence $;^{74}$ but often the applicability of the licensed plans or invention to the licensee's needs will not be ascertainable until they are transformed and actually used by the licensee. ${ }^{7 \varepsilon}$ Moreover, if trade secrets are involved, the licensor might be reluctant to allow inspection.

Even if inspection is made or demanded by the licensor and refused by the licensee, the licensor can nevertheless be held liable for defects whiclr would not have been ascertainable on examination and which render the licensed material unmerchantable ${ }^{76}$ or unsuitable for the licensee's particu-

72 See, e.g., Houston-Starr Co. v. Berea Brick \& 'Tile Co., 197 F. Supp. 492 (N.D. Ohio 1961); Wallower v. Elder, 126 Colo. 109, 247 P.2d 682 (1952); L. VoLd, supra note 67, at $437,439$.

${ }^{73}$ See, e.g., Himmelstein v. Budner, 93 F. Supp. 946 (D.D.C. 1950) (sale of entire business; faulty wiring); Marcos v. Texas Co., 75 Ariz. 45, 251 P.2d 647 (1952) (lease of service station; leaky underground tanks); Drumar Mining Co. v. Morris Ravine Mining Co., 33 Cal. App. 2d 492, 92 P.2d 424 (1939) (sale of used, complicated machinery; not suited to buyer's purpose); Luther v. Standard Conveyor Co., 252 Minn. 135, 89 N.W.2d 179 (1958) (sale of delicate machine; not suited to buyer's purposes).

74 Intrastate Credit Serv., Inc. v. Pervo Paint Co., 236 Cal. App. $2 d$ 547, 551, 46 Cal. Rptr. 182, 184 (1965) ; McCormick v. Hoyt, 53 Wash. 2d 338, 342-43, 333 P.2d 639, 642 (1959). It is not clear at precisely what point the consuner is relieved of the duty to inspeet before his purchase due to impracticability. Compare Marcos v. Texas Co., 75 Ariz. 45, 251 P.2d 647 (1952), with id. at 48, 251 P.2d at 650 (dissenting opinion).

75 If the licensee realizes that there is a likelihood that the plans and invention will not serve his needs, it is a fact indicating that lie lias assumed the risk of the transaction; if he has assumed the risk, no warranty will be implied. See, e.g., Stiefel Feed Co. v. Aerovent Fan Co., 148 F. Supp. 894 (S.D. Ohio), affd, 238 F.2d 859 (6th Cir. 1956).

76 See, e.g., Lindberg v. Coutches, 167 Cal. App. 2d Supp. 828, 334 P.2d 701 (Super. Ct. 1959); Moore v. Hubbard \& Jolinson Lumber Co., 149 Cal. App. 2d 236, 308 P.2d 794 (1957); see 1 Wricistox, Saces $\$ 234$, at 602 ; L. VoLd, supra note 67 , at 440. 
lar purpose. ${ }^{77}$ In determining what facts could be ascertained upon examination, the licensee's knowledge and experience are relevant. ${ }^{78}$

\section{Presence of Justifiable Reliance: A Prerequisite for the Warranty of Fitness}

Once a suppher realizes the particular purpose for which a product is to be used, ${ }^{79}$ and if the consumer has justifiably relied on him to provide goods suited for that purpose ${ }^{80}$ le warrants that the product is fit for that purpose. The requirement of justifiable reliance is especially acute in licensing transactions. Because the parties are often on a par in their levels of expertise, it will be difficult to determine, first, whether the licensee has in fact rehed on the licensor's skill and judgment, and, second, whether sucli reliance was justified. For example, it is plain that any consumer relies on his own judgment to some extent; ${ }^{81}$ recognizing this fact, the courts in sales cases state the rather obvious rule that "the buyer may rely on his own judgment as to some matters and on the seller's skill and judgment as to others." ${ }^{182}$ However, exactly which matters must be left to the seller in

77 See, e.g., In re Belle-Moc, Inc., 182 F. Supp. 429, 436-38 (S.D. Me. 1960) ; Tremeroli v. Austin Trailer Equip. Co., 102 Cal. App. 2d 464, 477, 227 P.2d 923, 931 (1951); see I WIILISTON, SALES § 235, at 607-10.

The supplier is hable for the latent defects even if lie could not have ascertained them on inspection. E.g., Vlases v. Montgomery Ward \& Co., 377 F.2d 846 (3d Cir. 1967).

78 See, e.g., Appliance Corp. v. Speed Queen Corp., 186 F.2d 798 (7th Cir. 1951); Singleton v. Dunn, 71 Ariz. 150, 224 P.2d 643 (1950); Wallower v. Elder, 126 Colo. 109, 247 P.2d 682 (1952); Vacuum Concrete Corp. of America v. Berlanti Constr. Co., 206 Pa. Super. 548, 214 A.2d 729 (1965); Leishman v. Kamas Valley Lumber Co., 427 P.2d 747 (Utah 1967); UNIForar COMrMErcial CODE \& 2-316, Comment 8; L. Vold, supra note 67, at $437,439$.

70 See, e.g., McCormick v. Hoyt, 53 Wash. 2d 338, 342, 333 P.2d 639, 642 (1959); Unteorar CoMmarctal Code § 2-315 \& Comment 1.

80 UnIForar CoMramercial Code § 2-315 \& Comment 1; UnTFORM SALES ACT § 15(1); e.g., Odell v. Frueh, 146 Cal. App. 2d 504, 509, 304 P.2d 45, 49 (1956); Catamia v. Brown, 4 Conn. Cir. 344, 231 A.2d 668 (1967); 1 WInliston, Sales $\$ 235$, at 607-10.

However, a consumer need not "prove reliance ... in order that he may recover for the breach of an implied warranty of merchantability." Vitro Corp. of America v. Tesas Vitrified Supply Co., 71 NM. 95, 106-07, 376 P.2d 41, 49 (1962); accord, Torrance v. Durisol, Inc., 20 Conn. Supp. 62, 65, 122 A.2d 589, 591 (Super. Ct. 1956); see Prosser, The Implied Warranty of Merchantable Quality, 27 MINN. L. REv. 117, 133 (1943). Compare UNIFORM COMIMERCIAI CODE § 2-315 and UNIFORMI SALES ACT \& 15(1) with Uniforar Comarerctal Code § 2-314 and Untrorar SaIes Act § 15(2).

81 See, e.g., Kurriss v. Conrad \& Co., 312 Mass. 670, 46 N.E.2d 12 (1942) ; Leishman v. Kamas Valley Lumber Co., 427 P.2d 747 (Utah 1967).

82 Drager v. Carlson Hybrid Corn Co., 244 Iowa 78, 84, 56 N.W.2d 18, 22 (1952); accord, Himmelstein v. Budner, 93 F. Supp. 946, 949 (D.D.C. 1950) ; Kurriss v. Conrad \& Co., 312 Mass. 670, 681, 46 N.E.2d 12, 18 (1942); Fossum v. Timber Structures, Inc., 54 Wasl. 2d 317, 335, 341 P.2d 157, 168 (1959). 
order that the buyer will be afforded the remedy of an implied warranty of fitness is not clear. ${ }^{83}$

In some cases there is obviously no reliance. For example, a consumer who gives a building contractor or manufacturer plans and specifications to follow, has no action for breach of an implied warranty of fitness if the building ${ }^{84}$ or machine ${ }^{85}$ is not suited to his needs. By analogy, if a licensee has requested a patent, know-liow or teclinical assistance to accomplisl a certain purpose, the licensee slould have no implied warranty of fitness remedy if lie has miscalculated his needs.

If a licensee whose skill and knowledge are equal to that of the licensor has inspected the materials to be licensed, he has probably not justifiably relied upon the licensor. ${ }^{86}$ It is also important to consider the licensor's occupation, ${ }^{87}$ his experience with the subject matter being licensed, ${ }^{88}$ and his understanding of the licensee's intended use. ${ }^{80}$ Finally, the risk of the transaction should be taken into account: ${ }^{.0}$ If the licensee realized that the

83 In Miller v. Lawlor, 245 Iowa 114, 66 N.W.2d 267 (1954), a case involving promissory estoppel, the court stated that the reliance requirements for estoppel were fulfilled so long as the plaintifi would not have acted without the defendant's assurances. A negative criterion for warranty of fitness purposes, formulated from the above, might be the following: Reliance requirements are not met if the consumer would have purchased, irrespective of whom the supplier was or what assurances the supplier impliedly or expressly made as to the fitness of the product for the consumer's purposes.

84 Compare Presiding Bishop v. Cavanaugh, 217 Cal. App. 2d 492, 32 Cal. Rptr. 144 (1963), with Fossum v. Timber Structures, Inc., 54 Wash. 2d 317, 341 P.2d 157 (1959).

85 Compare Automatic Welding Mach. Co. v. Lauer \& Associates, 347 Mich. 218, 79 N.W.2d 627 (1956), with Luther v. Standard Conveyor Co., 252 Minn. 135, 89 N.W.2d 179 (1958). See also Standard Packaging Corp. v. Continental Distilling Corp., 378 F.2d 505 (3d Cir. 1967).

80 See, e.g., Gillette v. Kelling Nut Co., 185 F.2d 294 (4th Cir. 1950); Houston-Starr Co. v. Berea Brick \& Tile Co., 197 F. Supp. 492 (N.D. Ohio 1961) ; Vacuum Concrete Corp. of America v. Berlanti Constr. Co., 206 Pa. Super. 543, 214 A.2d 729 (1965); 1 WnIIstoN, Sales $\$ 234$, at 602, § 235, at 609-10. Compare Milwaukee Tank Works v. Metals Coating Co. of America, 196 Wis. 191, 193-94, 218 N.W. 835, 836 (1928), which involved a license to use a very complicated patented machine. Even though the jury found that the licensee did not rely on the licensor, the trial court "properly changed tbe jury's answer to this question, [because] nothing short of an actual trial or experiment would determine whether the device would perform the work for which it was procured."

87 See Boemg Airplane Co. v. O'Malley, 329 F.2d 585 (8th Cir. 1964); Holmes Packaging Mach. Corp. v. Bingham, 252 A.C.A. 926, 60 Cal. Rptr. 769 (1967); UnIForar CoMaMercial Code $\S 2-316$, Comment $8 ; 1$ WIItiston, Sales $\S 235$, at 608 .

88 See Singleton v. Dunn, 71 Ariz. 150, 155, 224 P.2d 643, 646 (1953) ; Drumar Mining Co. v. Morris Ravine Mining Co., 33 Cal. App. 2d 492, 498-99, 92 P.2d 424, 427-28 (1939).

80 See Standard Packaging Corp. v. Continental Distilling Corp., 378 F.2d 505 (3d Cir. 1967); Stiefel Feed Co. v. Aerovent Fan Co., 148 F. Supp. 894, 897-98 (S.D. Ohio), affd, 238 F.2d 859 (6th Cir. 1956); Drumar Miming Co. v. Morris Ravine Mining Co., 33 Cal. App. 2d 492, 498-99, 92 P.2d 424, 427-28 (1939); L. Vorp stipra note 67, at 439.

90 See UnIform Comamerctal Code $\$ 2-315$, Comnient $3 ; 1$ Whiliston, Sales $\$ 231$. 
know-how or patent was new and untried, ${ }^{91}$ or that the hicensor did not know if his invention, plans or technical assistance could accomplish the licensee's purposes, ${ }^{92}$ lie has not justifiably relied.

\section{Problems in Applying the Implied Warranty of Merchantability to Licenses}

The warranty of merchantability requires that the supplier qualify as a merchant, ${ }^{93}$ dealer ${ }^{04}$ or manufacturer ${ }^{95}$ with respect to the product supphed. If he so qualifies, the products he supplies are warranted both to meet the general standards of like products in the trade and to be reasonably suited for the ordinary purposes for whicli sucli products are used..$^{96}$ Two major problems are presented when the warranty of merchantability is considered in the context of licenses.

\section{The Licensor as a "Dealer"}

The first problem is whether and under what circumstances a licensor qualifies as a merchant, dealer or manufacturer. In some cases the hicensors are obviously merchants or dealers in patents or know-how; ${ }^{97}$ in other cases, the licensor is often a manufacturer who regularly licenses the use of equipment which he has made. ${ }^{88}$ But even if the licensor is not one who usually deals in patents, know-low or technical assistance of the kind he licenses in a particular instance, he is nonetheless treated like a dealer, merchant and manufacturer if he is one who

by his occupation holds himself out as having knowledge or skill peculiar to the practices or goods involved in the transaction or to whom such knowledge or skill may be attributed by his employment of an agent ... or other intermediary who by his occupation holds himself out as having such knowledge or skill.99

91 See, e.g., Thielman v. Reinsch, 103 Ark. 307, 146 S.W. 525 (1912); Vacuum Concrete Corp. of America v. Berlanti Constr. Co., 206 Pa. Super. 548, 214 A.2d 729 (1965).

82 See, e.g., Stiefel Feed Co. v. Aerovent Fan Co., 148 F. Supp. 894 (S.D. Ohio), aff'd, 238 F.2d 859 (6th Cir. 1956); Derfus v. Stoelting Bros. Co., 223 Wis. 205, 270 N.W. 40 (1936).

93 UNIroRM CoMrMierciat CODE \& 2-314(1).

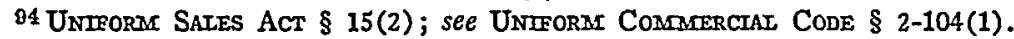

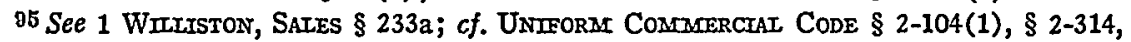
Comment 2.

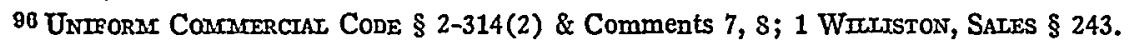

07 See, e.g., Automatic Radio Mfg. Co. v. Hazeltine Research, Inc., 399 U.S. 827 (1950) (license covered 570 patents and 200 patent applications).

98 See, e.g., General Talking Pictures Corp. v. Sliea, 187 Ark. 568, 61 S.W.2d 430 (1933); Vacuum Concrete Corp. of America v. Berlanti Constr. Co., 206 Pa. Super. 548, 214 A.2d 729 (1965).

99 Untrorar Commarcial Code § 2-104(1); see Uniforar Conamerctal Code \$ 2-315, Comment 4; 1 Wricrston, SALES § 235, at 607-08. 
In many cases a licensor masters his product mucli more than the typical merchant because he has personally created it. A supplier is cliarged with a warranty of mercliantability because he is expected to be experienced with his product. ${ }^{100}$ Consequently, if a licensor is experienced with the licensed plans, information and ideas, he should be held to warrant that they are merchantable. In short, he should not be exculpated from an otherwise legitimate hability simply because he has not been regularly dealing in his products or because he might not meet traditional definitions of "merchant."

\section{Merchantability of Licensed Material}

The second problem in applying the warranty of merchantability to licenses is the determination of whether licensed patents, know-how or techmical assistance can ever be considered "unmerchantable." The Uniform Commercial Code's defimition of merchantability presupposes both an established "trade" in which goods must "pass without objection"101 as well as an established "use" for whicli the goods must be "fit for the ordinary purposes."102 There will generally be neither an established trade nor an established use by which the merchantability of licensed materials can be judged because of their novelty. Nonetheless, the standards of merchantability of the Uniform Commercial Code can be adapted to licensed materials.

The standards of merchantability-in contradistinction to those for the warranty of fitness for a particular purpose-are not as concerned with the consumer's expectations as with the use whicl the manufacturer or discoverer contemplated when the product was conceived or put on the market. ${ }^{103}$ Therefore, within the general policies of the Uniform Commercial Code, hicensed material is unmerchantable if it is not reasonably suited to the general use and purpose for which it was discovered or developed. ${ }^{104}$ For example, if a licensor gives the licensee plans, advice and formulae for making tires, and if tires cannot be made from the licensed materials, or if

100 See Holmes Packaging Mach. Corp. v. Bingham, 252 A.C.A. 926, 938-39, 60 Cal Rptr. 769, 776-77 (1967); 1 WirlistoN, SAIEs $\$ \S 231,233$; L. Vord, supra note 67, at 435; cf. Singleton v. Dunn, 71 Ariz. 150, 155, 224 P.2d 643, 646 (1950); Drumar Mining Co. v. Morris Ravine Mining Co., 33 Cal. App. 2d 492, 498, 92 P.2d 424, 427 (1939).

101 UNIFORM COMEMTERCTAL CODE \& 2-314(2)(a).

$102 I d . \S 2-314(2)$ (c).

103 See Crotty v. Shartenherg's-New Haven, Inc., 147 Conn. 460, 162 A.2d 513 (1960); 1 Wrizston, SAIES $\S 243$, at 642 (inerchantability requires that a product "shall be reasonably suitable for the ordinary uses for which it was manufactured").

104 "The question is ... whether machines constructed under the patents ... are of practical utility for the uses and purposes intended by the patentee ...." Herman v. Gray, 79 Wis. 183, 190, 48 N.W. 113, 115 (1891); of. UNIFORM CoMAMERcrar Code § 2-314, Comment 6. 
the devices manufactured do not function as ordinary tires, the plans, advice and formulae are unsuited for the general purposes for which they were designed and are unmerchantable. ${ }^{105}$ But if the licensee has bargained for no more than the right to develop obviously inadequate ideas, plans and formulae, no warranties will arise. ${ }^{106}$

A hicensee might be afforded the remedies of both warranties of fitness and of merchantability if the general use of the hicensed material is also the hicensee's intended, particular use. ${ }^{107}$ Even if there is no remedy on a warranty of fitness because the licensor was not informed of the hicensee's intended use, or because the licensee did not justifiably rely on the licensor, a remedy for breach of an implied warranty of merchantability is available to the licensee if the materials are not reasonably suited to their general uses.

\section{E. Determination of Breach of Implied Warranties in Licenses}

General guidelines of sales law can be used im most license cases to determine whether there has been a breach of warranty. However, a special word of caution is in order when considering patent and know-how licenses.

While certain machinery for certain purposes may closely approximate perfection in its operation, many kinds of machinery and processes are extremely valuable and constitute a great improvement over prior methods of doing certain things, although from the very nature of the case, perfect results are impossible. In such cases, reasonable fitness for the purpose intended is to be judged by a comparative standard .....108

Applying such a standard where one out of two of the licensee's grape shipinents were free from inold before using the licensor's antimold device and five out of seven were free from mold after using the device, it was held that the device was reasonably suited for the licensee's purposes. ${ }^{109} \mathrm{In}$

105 Cf. Bobrick Chem. Co. v. Prest-O-Lite Co., 160 Cal. 209, 116 P. 747 (1911); Holmes Packaging Mach. Corp. v. Bimgham, 252 A.C.A. 926, 60 Cal. Rptr. 769 (1967); Nettograph Mach. Co. v. Brown, 28 Okla. 436, 114 P. 1102 (1911).

106 See, e.g., Harris v. Umited Automatic Cigarette Co., 114 Cal. App. 583, 300 P. 71 (1931).

107 See Frigorifico Wilson de la Argentina v. Weirton Steel Co., 62 F.2d 677, 679 (4th Cir. 1933); Crotty v. Shartenberg's-New Haven, Inc., 147 Conn. 460, 162 A.2d 513 (1960); Uniforar Commiarciad Code § 2-315, Comment 2; 1 Williston, Sales $\S 235$, at 605 .

108 Lawson v. Rusconi, 112 Cal. App. 366, 369, 296 P. 628, 630 (1931).

109 Id. at $368-69,296$ P. at 630 . However, this case was decided under the Umiform Sales Act which required of the warranty of fitness only that a product "be reasonably fit" for the uses intended. UnIForar Sales ACT \& 15(1) (emphasis added). The Uniform Commercial Code requires that a product "shall be fit," \& 2-315, possibly indicating a more stringent test for the warranty of fitness. Today the warranty of merchantability is generally interpreted as requiring reasonable fitness for the purposes for which a product is 
some cases, therefore, if it would be unreasonable to expect absolute efficiency, a relative improvement may satisfy the warranty requirements.

On the other hand, if the licensee receives patents and know-how to produce widgets, the issue is more easily resolved because either the patents and know-how will serve to produce widgets in accordance with the contract specifications or they will not. Only in the latter instance is there a possibility of warranty liability. Likewise, if a patented process is licensed for a highly specialized use which demands one hundred per cent efficiency, anything falling short of this will render the process unfit. ${ }^{110}$ However, if such a process is reasonably fit for its general uses and the licensee has not justifiably relied on the licensor to provide him with a process for this highly specialized purpose, there will be no warranty liability. The absence of justifiable reliance precludes a warranty of fitness ${ }^{111}$ and the reasonable fitness of the process for its general uses precludes a warranty of merchantability. ${ }^{112}$ Consequently, the nature of the materials to be licensed and the licensee's expectations when he has justifiably relied on the licensor will control in determining whether an implied license warranty has been breached.

\section{III}

\section{IMPLIED WARRANTIES IN PATENT LICENSES}

\section{A. Special Rules of Patent Law}

Two legal principles of patent law miglt be construed to indicate that no warranties of a patent's usefulness could ever arise in patent licenses. The first principle is that patent licenses do not import warranties of the patent's validity. ${ }^{113}$ In other words, a licensee is not assured that the li-

normally sold. See Schipper v. Levitt \& Sons, Inc., 44 N.J. 70, 92, 207 A.2d 314, 326 (1965); UNIFORM COMOMERCIAI CODE \& 2-314 \& Comment 8.

110 See, e.g., Milwaukee Tank Works v. Metals Coating Co. of America, 196 Wis, 191, 218 N.W. 835 (1928).

111 See, e.g., Gillette v. Kelling Nut Co., 185 F.2d 294 (4th Cir, 1950); Johnson v. Brewer-Titchener Corp., 28 F. Supp. 1002 (N.D.N.Y. 1939); UNIFORM Cosmmercuar CodE \& 2-315 \& Comment 1 .

112 See text accompanying note 104 supra.

113 See, e.g., Plastic Lens Co. v. Butterfield, 366 F.2d 338, 342 n.3 (9th Cir. 1966); 4-One Box Mach. Makers v. Wirebounds Patents Co., 131 Me. 356, 364, 163 A. 167, 171 (1932); Eno v. Prime Mfg. Co., 314 Mass. 686, 695, 50 N.E.2d 401, 407 (1943); R. Eitss, Patens licenses, supta note 23, at 216; 4 A. Watker, Watker on Pateasts $\S 403$ (2d ed. A. Deller 1965) [hereinafter cited as WATFER].

If a patent under which a licensee las been operating is invalid, the licensce will not be liable for payments of royalties either after lie has repudiated the license, Crew v. Flanagan, 242 Minn. 549, 65 N.W.2d 878 (1954), or after an eviction, Drackett Chem. Co. v. Chamberlain Co., 63 F.2d 853 (6th Cir. 1933). See also Patterson-Ballagli Corp. v. Byron Jackson Co., 145 F.2d 786 (9th Cir. 1944); Wynne v. Allen, 245 N.C. 421, 96 S.E.2d 422 (1957). The licensee is liable for royalties prior to the repudiation or the eviction. See, e.g., Lathrop v. Rice \& Adams Corp., 17 F. Supp. 622 (W.D.N.Y. 1936). 
censor's patent has actually met all of the requirements of the patent laws. ${ }^{114}$ The second principle is that a vahilly patented invention must be useful. ${ }^{115}$ It might be argued, therefore, that since there is no warranty of validity, there can be none of usefulness. However, such a conclusion is fallacious. ${ }^{118}$

First, in addition to requiring usefulness, an invention requires novelty to be valid; ${ }^{112}$ therefore, a patent might be adjudged invalid because of preemption by a prior patent. If patent licensors impliedly warranted the validity of their patents they would be warranting that, among all the manifold, previously patented inventions, theirs was unique. Given the patentee's limited knowledge of prior patents and the patent office's issuance of letters patent for his invention, so long as he does not know that his invention has been preempted by a prior patent, he is no more capable of evaluating his invention's novelty than is the licensee. Consequently, the licensor, like an assignor, ${ }^{118}$ is not held to warrant that his invention is valid. ${ }^{119}$ However, a patent hicensor can generally be expected to have knowledge of the usefulness of his invention. The utility, untike the novelty, is reasonably within the hicensor's immediate competence, and the reasons for not warranting the patent's validity are not applicable when utility alone is considered.

Second, even if the reasoning which leads to the conclusion that there can be no implied warranties of a patent's usefulness was not fallacious, the two principles of patent law would indicate only that a hicensor does not warrant that his patent is useful so as to qualify as a validly patented invention. However, the usefulness required of patent law is not the same as that required of contract law of implied warranty. ${ }^{120}$ For example, a li-

114 See 1 WALKER \$ 83.

115 See 35 U.S.C. $\$ 101$ (1964); see R. EliIs, PATENT Clanars $\$ 357$ (1949); 1 WaLKER $\$ \S 83,85-86$; see also Graham v. John Deere Co., 383 U.S. 1, 5-10 (1966).

116 It would of course be illogical since the reasoning which leads to the conclusionvahidy imphes usefulness, no vahdity, therefore no usefulness-commits the fallacy commonly called the denial of the antecedent. The fallacy is more easily illustrated by the following: Roses imply flowers; no roses, therefore no flowers. But there might be other flowers, such as dahhias or mums.

11735 U.S.C. $\$ \S 101,102$ (a)-(b) (1964); see R. ELIIS, supra note 115, $\$ \$ 357,360$; 1 WALKER § 54. There is the additional requirement of "non-obviousness." 35 U.S.C. § 103 (1964), construed in Graham v. John Deere Co., 383 U.S. 1, 10-19 (1966); see generally id. at $3-19$.

118 See 4 WALKER \& 355.

110 See Eastern States Petroleum Co. v. Universal Oil Prods. Co., 22 Del. Ch. 333, 337-40, 2 A.2d 138, 140-41 (Ch. 1938); cf. Eno v. Prime Mfg. Co., 314 Mass. 686, 695-97, 50 N.E.2d 401, 407-08 (1943).

120 The usefulness required of the patent laws is a minimal standard which may or may not correspond to the needs of a licensee. The patent laws' requirement is designed to prevent frivolous applications for patents; it should not be used in contract law which is designed to protect the expectation interests of the contracting parties and assure an honest 
censor's patented invention might concededly be very useful for some purposes and yet be totally unsuited for the general purposes for which it was hicensed or for the particular purpose of a licensee who has justifiably rehed on the hicensor.

\section{B. Risk of Patent Licenses}

One factor which militates against the implication of warranties of merchantabihty and fitness in patent licenses is the inherently new, untried nature of inventions. However, the risk of a transaction is not alone determinative of whether warranties will be implied. The important consideration is which of the hicensing parties has assumed the risk of the transaction. ${ }^{121}$ In cases where it can be shown that the licensor assumed the risk of the license, recovery should be allowed. ${ }^{122}$ Of course the fact that a transaction is risky is significant in determining whether the hicensee has justifiably rehed on the licensor ${ }^{123}$ and exactly what the hicensee has bargained for. ${ }^{124}$

\section{Reliance and Examination}

In patent license cases the licensor will usually have complete knowledge of the plans, processes and information which compose his invention. However, where the licensor is an assignee of the patentee or a licensee with rights to sublicense, ${ }^{125}$ the licensor might have little or no knowledge of the invention because he did not create it: and possibly never observed it function. Likewise, a licensee will generally have thorough knowledge and skill to evaluate the patent; however, there will be exceptions. Therefore, the licensor's and licensee's relative skill and judgment will be important to the issue of justifiable reliance. ${ }^{128}$

The hicensee's skill and knowledge will also be significant in determining whether there has been a waiver of warranties due to examination. The

and fair means of transacting business. As the Supreme Court stated, controversies involving "contracts relating to patents, or licenses under patents" are not "patent cases." Henry v. A.B. Dick Co., 224 U.S. 1, 15 (1912). The law of patents sloould be applied when it is directly relevant to a patent dispute; it should not, lowever, be employed to confound contract law.

121 See 1 Winliston, Sales \$ 231, at 591-92; cf. UnIForm Commercial Code \$ 2-315, Comment $3, \S 2-303$.

122 See Bobrick Chem. Co. v. Prest-O-Lite Co., 160 Cal. 209, 116 P. 747 (1911);

Luther v. Standard Conveyor Co., 252 Minn. 135, 39 N.W.2d 179 (1958); Milwaukee

Tank Works v. Metals Coating Co. of America, 196 Wis. 191, 218 N.W. 835 (1928). 123 Discussed in text accompanying notes 125-32 infra.

124 See, e.g., Stiefel Feed Co. v. Aerovent Fan Co., 148 F. Supp. 894 (S.D. Ohio), aff'd, 238 F.2d 859 (6th Cir. 1956).

125 See 4 WALKER § 408, at 633.

126 See, e.g., Boeing Airplane Co. v. O'Malley, 329 F.2d 585, 592-93 (8th Cir. 1964); Thielman v. Reinsch \& Owens, 103 Ark. 307, 146 S.W. 525 (1912): L. Voud, supra note 67 , at 439 . 
licensee will usually have an opportunity to examine the patented device or process because a patent is a matter of public information; ${ }^{127}$ lowever, examination might be impracticable if it would be necessary to transform the ideas and plans into actual structures to provide an adequate examination. Where examination is practical, the licensee's skill and knowledge are important in determining what facts he could reasonably have ascertained. ${ }^{128}$ Moreover, if a licensee with considerable knowledge has examined a patented device or process, it is likely that he has not justifiably relied on the licensor. ${ }^{129}$

The licensor's knowledge will also be relevant in determining whether he can be considered a merchant, dealer or manufacturer for the purpose of the warranty of merchantability. ${ }^{130}$

If a licensee has justifiably relied on the licensor to supply him with a patent which is suited to his particular needs, the licensor should be hable for losses if the patent is not suited to the hicensee's needs. The hicensor would be liable for losses caused by defects which were not ascertainable by the licensee on examination; or, if there was no opportunity for a practical examination, the hicensor would be hable for any defects. ${ }^{131}$ The licensor's liability might be based on both warranties. ${ }^{132}$

${ }^{127}$ See Sandlin v. Johnson, 141 F.2d 660,661 (8th Cir. 1944); 35 U.S.C. $\S 112$ (1964); 4 WALKER $\S 206$, at 5.

128 See, e.g., Johnson v. Brewer-Titchener Corp., 28 F. Supp. 1002 (N.D.N.Y. 1939); Leishman v. Kamas Valley Lumber Co., 427 P.2d 747 (Utah 1967).

${ }^{129}$ See, e.g., Holmes Packaging Mach. Corp. v. Bingham, 252 A.C.A. 926, 60 Cal. Rptr. 769 (1967); Owens v. National Hatchet Co., 147 Iowa 393, 121 N.W. 1076 (1910); Vacuum Concrete Corp. of America v. Berlanti Constr. Co., 206 Pa. Super. 548, 214 A.2d 729 (1965); Derfus v. Stoelting Bros. Co., 223 Wis. 205, 270 N.W. 40 (1936).

130 See text accompanying notes 97-100 supra.

131 See, e.g., Moore v. Hubbard \& Johnson Lumber Co., 149 Cal. App. 2d 236, 308 P.2d 794 (1957); Webster v. Klassen, 109 Cal. App. 2d 583, 241 P.2d 302 (1952); Luther v. Standard Conveyor Co., 252 Minn. 135, 89 N.W.2d 179 (1958); Milwaukee Tank Works v. Metals Coating Co. of America, 196 Wis. 191, 218 N.W. 835 (1928).

132 See cases and authorities cited note 107 supra and accompanying text.

It has been asserted that there are probably no implied warranties of commercial utility in patent licenses. Nordhaus, Patent License Agreements, 21 Bus. LAw. 643, 648 (1966) (citing Apphance Corp. v. Speed Queen Corp., 186 F.2d 798 (7th Cir. 1951)); R. Elits, Patent Licenses, supra note 23 , at $\$ 215$ (citing Bird's-Eye Veneer Co. v. Franck-Philipson \& Co., 259 F. 266 (6th Cir. 1918); Van Norman v. Barbeau, 54 Minn. 388, 55 N.W. 1112 (1893); Derfus v. Stoelting Bros. Co., 223 Wis. 205, 270 N.W. 40 (1936)). However, in Appliance Corp., supra, the court emphasized that the licensor's suit was for machinery which the licensee had purchased and received, that the purpose of the license which the hicensee claimed to have been breached was for "development of a satisfactory washing machine," and that the licensee had manufactured 677 machines before the license was ever entered. 186 F.2d at 800-03 (emphasis added). In Bird's-Eye, supra, the court explicitly reserved judgment on the issue of warranties being inplied in licenses, but noted that the licensee was at least on an equal footing with the ficensor with respect to chemical knowledge and better informed as to the patent's potential commercial success. $259 \mathrm{~F}$. at 267 . Moreover, and more important, when the "contracts were 


\section{IV}

\section{IMPIIED WARRANTIES IN KNOW-HOW LICENSES}

The know-how which a licensee receives might take various forms. The most general type of know-how is a trade secret. ${ }^{133} \mathrm{Know}$-how can include patentable but unpatented inventions, ${ }^{134}$ as well as other types of information and ideas such as economic analyses, computer programs, maps, production processes and art designs. ${ }^{135}$ As long as the trade secret retaims its secrecy ${ }^{138}$ it can be much more valuable than a patented invention since,

made, the [licensee] knew all about the failure of the process . . . . It merely was hoping and believing that the defects had been overcome." 259 F. at 268. Similarly, in Derfus, supra, "[t]lye lack of perfection was apparent, but it performed well enough to interest [the licensee] and to breed a hope of further improvement." 223 Wis. at $207,270 \mathrm{~N} . \mathrm{W}$. at 41. Consequentiy, in each of these three cases, the licensees had fully examined the invention and knew that development or further improvement would be needed when they entered their licenses; they received all that they had bargained for and the courts correctiy denied them relief.

In Van Norman, supra, the court, quoting from the 1879 case of Wilson v. Hentges, 26 Minn. 288, 3 N.W. 338 (1879), stated: "The law does not look to the degree of utility. It simply requires that it slrould be capable of use, and that the use be such as sound morals and policy do not discountenance or prohibit." 54 Minn. at 393, 55 N.W. at 1113. However, the decision is poorly reasoned. First, the requirements that the court states are those used to determine a patent's validity; that is, whether the invention was useful to meet the requirements of the patent laws. See 1 WALIJPR 889 , at 504. But it is wellestablished that cases involving "contracts relating to patents, or licenses under patents" are not "patent cases." Henry v. A.B. Dick Co., 224 U.S. 1, 15 (1912). Second, in a more recent case, the Minnesota supreme court stated: "Failure of consideration justifying the licensee of a patent in refusing to pay the stipulated royalty simply means that he should not be compelled to pay where lie did not receive that for which the payment was promised." Miller v. O.B. McClintock Co., 210 Minn. 152, 162, 297 N.W. 724, 730 (1941) (citation omitted). In short, whereas the Miller court recognized that the parties' expectation interests are of paramount importance in a license case, the Van Norman court did not and crroneously applied primciples of patent law to a contract case.

${ }^{133} \mathrm{~A}$ trade secret may consist of any formula, pattern, device or compilation of information which is used in one's business, and which gives him an opportunity to obtain an advantage over competitors who do not know or use it. . . A trade secret is a process or device for continuous use in the operation of the business.

Restatement of TorTs \& 757, comment $b$ (1939); see Hooker Chem. Corp. v. Velsicol Cliem. Corp., 235 F. Supp. 412, 424-25 (N.D. Tenn. 1964); National Rejectors, Inc. v. Trieman, 409 S.W.2d 1, 18-19 (Mo. 1966).

134 See, e.g., A.O. Smith Corp. v. Petroleum Iron Works Co., 73 F.2d 531 (6th Cir. 1934); Dunlavey, Protection of the Inventor Outside the Patent System, 43 CarIf. L. Rev. $457,459-60$ (1955). However, the owner of such a trade secret runs the risk that soneone else will discover the same idea and patent it. See, e.g., Mycalex Corp. v. Pemco Corp., 64 F. Supp. 420, 423 (D. Md. 1946); 4 WALKER $\S 206$, at 4-5; Dunlavey, sutpra at 467-69.

135 See L. ECKstrom, LICENSING IN Foreign Operátions at VI.E, VI.E.1 (1958); RESTATEMENT OR TORTS $\$ 757$, coniment $b$ (1939).

136 See Reynolds Metals Co. v. Skinner, 166 F.2d 66 (6th Cir.), cert. denied, 334 U.S. 858 (1948); Hooker Chem. Corp. v. Velsicol Chein. Corp., 235 F. Supp. 412 (W.D. Tenn. 1964); National Rejectors, Inc. v. Trieman, 409 S.W.2d 1 (Mo. 1966); Annot., 9 A.L.R.3d 665, 673 (1966); CaI. CTy. Code § 983(b) (West 1954); 4 WaLTJ $§$ 206, at 4-5. 
unlike the patented invention, ${ }^{137}$ it does not become public property after a set number of years.

The typical know-how licensor will almost certamly be familiar with the material he licenses. He lias generally discovered, developed and used the know-how over a period of time, thereby having an opportunity to evaluate it. Consequently, know-liow licensors, probably to a greater degree than patent licensors, ${ }^{138}$ can be expected to be more knowledgeable about the potential usefulness of the materials they license. Furthermore, whereas the patent is public information, ${ }^{139} \mathrm{know}-\mathrm{low}$ is secret, and the know-how licensor might be reluctant to allow inspection before the license is completed ${ }^{140}$ even though his trade secret is protected from misappropriation. ${ }^{141}$ Even if there is an opportunity to examine the material and the licensee has adequate skill and knowledge to do so meaningfully, efficient inspection could require as much work as the original research and therefore be impracticable. ${ }^{142}$

While these general observations indicate that a know-how licensee would more often be justified in relying on his licensor and less often be able to make a reasonable inspection than a comparable patent licensee, it slould not be concluded that the know-how licensor will usually be lield to warranty hability. For example, the licensee miglit have adequate knowledge and skill to examine the know-how and miglut have been given the opportunity to do so. ${ }^{143}$ Also, other facts which would preclude the existence of implied warranties in other transactions would preclude them in knowlow licenses. Thus if the licensor makes it clear that he does not know if his know-llow will reasonably suit the licensee's purposes, the licensee will have no remedy on an implied warranty of fitness because there is no reliance. ${ }^{144}$ There might also be cases where the licensor does not qualify as a

137 Rights to a patented invention become public property after the patent's seventeenyear period expires. Brulotte v. Thys Co., 379 U.S. 29, 31 (1964). And the "use of royalty agreements that project beyond the expiration date of the patent is unlawful per se." Id. at 32 ; see 4 WALKER \$ 413 , at 677-79.

138 It is probable that a know-how licensor more often will have used his ideas under various conditions and on a large scale. The patent licensor might not go past the discovery and model stages when he hicenses his invention.

139 Case and authorities cited note 127 supra.

140 See 4 WAIKER $\$ 206$, at 4.

141 See Heyman v. A.R. Winarick, Inc., 325 F.2d 584, 587 (2d Cir. 1963); Schreyer v. Casco Prods. Corp., 190 F.2d 921 (2d Cir. 1951), cert. denied, 342 U.S. 913 (1952); Annot., 9 A.L.R.3d 665, 670-72 (1966); Restatenrens of Torts § 757 (1939); Dunlavey, supra note 134, at 464-67.

142 This would be especially true of that know-how which represents compilation of data, maps and similar research, as contrasted with discoveries and ideas.

143 See, e.g., Theilman v. Reinsch \& Owens, 103 Ark. 307, 146 S.W. 525 (1912); Emerson Elec. Mfg. Co. v. Printed Motors Inc., 252 N.X.S.2d 600, 613 (Sup. Ct. 1964); Derfus v. Stoelting Bros. Co., 223 Wis. 205, 270 N.W. 40 (1936).

144 See, e.g., Stiefel Feed Co. v. Aerovent Fan Co., 148 F. Supp. 894, 897-98 (S.D. Ohio), aff'd, 238 F.2d 859 (6th Cir. 1956). 
merchant for the purposes of the warranty of merchantability; for example, if the licensor just purchases the know-low as an investment and is not familiar with it, the licensee could not hold him for breach of an implied warranty of merchantability. ${ }^{145}$ If the licensee takes know-how whicll is obviously imperfect, lie has received what he bargained for and should not recover if the know-how is worthless or unsuited to his needs. ${ }^{140}$

\section{$\mathrm{V}$}

\section{IMPLIED WARRANTIES IN TECHNICAI, ASSISTANCE LICENSES}

Technical assistance licenses afford licensees the continuing guidance and aid of experts and technicians in establishing better methods of operation and overcoming day-to-day difficulties. ${ }^{147}$ These licenses provide that the licensor or persons employed by him will be available to the licensee for general consultation on particular problems, for supervisory work on certain aspects of the licensee's business, for training the licensee's employees, or for esoteric work sucl as repairing complicated machinery or designing computer programs. Technical assistance provisions are commonly included with know-how and patent licenses so that the licensed invention or information can be adapted to the licensee's particular needs and so that the licensee can be assured that it is propitiously exploited. ${ }^{148}$

\section{A. Technical Assistance Aspects of Licenses}

The teclinical assistance licensor warrants only that the experts and technicians whom he has made available to the licensee have the requisite skill and knowledge in light of the licensee's needs and that they will reasonably endeavor to use that skill and knowledge to aid the licensee. ${ }^{140}$ Of

145 See, e.g., Holmes Packaging Mach. Corp. v. Bingham, 252 A.C.A. 926, 60 Cal. Rptr. 769 (1967).

140 See, e.g., Harris v. United Automatic Cigarette Co., 114 Cal. App. 583, 300 P. 71 (1931); see also Lawson v. Rusconi, 112 Cal. App. 366, 296 P. 628 (1931).

147 See generally L. EckstroM, supra note 135, at VI.T.1.

148 See, e.g., Reynolds Metals Co. v. Skinner, 166 F.2d 66 (6th Cir.), cert. denied, 334 U.S. 858 (1948); Emerson Elec. Mfg. Co. v. Printed Motors Inc., 141 U.S.P.Q. 68, 252 N.Y.S.2d 600 (Sup. Ct. 1964) ; Vacuum Concrete Corp. of America v. Berlanti Constr. Co., 206 Pa. Super. 548, 214 A.2d 729 (1965); R. Eluts, Patent Licenses supra note 23, at \& 157.

149 See, e.g., Economy Fuse \& Mfg. Co. v. Raymond Concrete Pile Co., 111 F.2d 875, 878-79 (7th Cir. 1940); Dog River Boat Serv., Inc. v. The Frances D., 192 F. Supp. 759, 761 (S.D. Ala. 1961); Pepsi Cola Bottling Co. v. Superior Burner Serv. Co., 427 P.2d 833 (Alas. 1967); Gagne v. Bertran, 43 Cal. 2d 481, 489, 275 P.2d 15, 21 (1954); Audlane Lumber \& Builders Supply, Inc. v. D.E. Britt Assocs., Inc., 168 So. 2d 333 (Fla. App. 1964); Jackson v. Central Torpedo Co., 117 Okla. 245, 246 P. 426 (1926); 9 S. Winliston, Contracts \& 1012C (3d ed. W. Jaeger 1967) ; cf. Griswold v. Heat Inc., 108 N.H. 119, 229 A.2d 183 (1967).

The terminology which is used to describe the workman's duty varies. Some cases use imphed warranty teruninology. E.g., Economy Fuse \&: Mfg. Co. v. Raymond Concrete Pile Co., supra. Other cases rely only on neghigence terminology. E.g., Aegis Prods., Inc. v. 
course, if the licensee realizes that the experts possibly do not liave the requisite skill and only lopes that they might be of assistance to him, no warranties will be implied since the licensee lias assumed the risk of the agreement. $^{150}$

The technical assistance licensor does not warrant that the experts' and technicians' work and advice will be accurate or yield the results contemplated by the parties. ${ }^{151}$ If the experts and technicians are qualified in hight of the task undertaken, the licensee can lold the licensor only for their neghigent or intentional misconduct. ${ }^{152}$ By adopting these principles, the law recognizes the fallibility of the experts and technicians. As a result, if a licensor promises that he or an employee of his will work for the improvement or successful development of hicensed know-how or patents, the licensee camot hold the licensor liable for not achieving improvement or successful development. ${ }^{153}$ Likewise, if the experts and technicians, though generally qualified, fail to adapt licensed know-how or patents to the licensee's needs due to a nonneghigent, unintentional error of judgment, the licensee could not hold the licensor for this failure of the technical assistance. ${ }^{154}$

\section{B. The Relationship of Technical Assistance to Know-How and Patents}

The law of impled warranty has been plagued by the principle that warranty liability for defective goods does not attach to a contract if the

Arriflex Corp. of America, 25 A.D.2d 639, 268 N.Y.S.2d 185 (1966); Jackson v. Central Torpedo Co., supra. The results of the cases, however, are the same: The workman must have reasonable skill in light of the task undertaken and must exercise it as would a prudent workman in his profession. The cases are lucidly and authoritatively analyzed in Pepsi Cola Bottling Co. v. Superior Burner Serv. Co., supra at 838-43.

150 E.g., Derfus v. Stoelting Bros. Co., 223 Wis. 205, 270 N.W. 40 (1936); see Johnson v. Brewer-Titchener Corp., 28 F. Supp. 1002, 1004 (N.D.N.Y. 1939) (icense provision that licensor would provide hicensee with a "thoroughly perfected," "marketable" product held to be "puffing talk"). But see Kraus v. General Motors Corp., 120 F.2d 109 (2d Cir. 1941).

101 See Gagne v. Bertran, 43 Cal. 2d 481, 275 P.2d 15 (1954); Gautier v. General Tel. Co., 234 Cal. App. 2d 302, 44 Cal. Rptr. 404 (1965); Bonadiman-McCain, Inc. v. Snow, 183 Cal. App. 2d 58, 6 Cal. Rptr. 52 (1960); Aegis Prods., Inc. v. Arriflex Corp. of America, 25 App. Div. 2d 639, 268 N.Y.S.2d 185 (1966). But see Broyles v. Brown Eng'r Co., 275 Ala. 35, 151 So. 2d 767 (1963).

152 See, e.g., Pepsi Cola Bottling Co. v. Superior Burner Serv. Co., 427 P.2d 833 (Alas. 1967); Roberts v. Karr, 178 Cal. App. 2d 535, 3 Cal. Rptr. 98 (1960).

153 See cases cited note 150 supra; cf. cases cited note 151 supra.

154 See Gagne v. Bertran, 43 Cal. 2d 481, 275 P.2d 15 (1954); Audlane Lumber \& Builders Supply, Inc. v. D.E. Britt Assocs., Inc., 168 So. 2d 333 (Fla. App. 1964); see also Roberts v. Karr, 178 Cal. App. 2d 535, 3 Cal. Rptr. 98 (1960) (surveyor not subject to warranty liability, but held for negligence). But see Broyles v. Brown Eng'r Co., 275 Ala. $35,38,151$ So. $2 \mathrm{~d} 767,770$ (1963) (holding civil engineers to implied warranty in performance of services). 
contract is predominantly one for services. ${ }^{165}$ This principle has had its greatest effect on "service" of food $\operatorname{cases}^{156}$ and cases involving a hospital which supplied contaminated blood or other defective products as part of its general "services."157 While this principle has now been generally rejected in the service of food cases, ${ }^{158}$ it retains vitality and wide acceptance in the cases involving lospitals. ${ }^{159}$ From these cases it miglit be argued that the presence of technical assistance provisions in a know-liow or patent license might negate any warranty of the patent or know-how. However, as has been noted, the principle underlying such an argument has generally been discredited; in the case of hospitals, the prevalence of the principle is explainable on the ground that the courts are reluctant to impose the absolute liability of a warranty on nonprofit, public service institutions. ${ }^{100}$ Therefore, for the same reasons which have led to the rejection of this principle in service of food cases, ${ }^{161}$ the presence of technical assistance provisions in a license slould not deny a licensee an otherwise proper warranty remedy if the know-how or patent is defective.

On the contrary, it miglit be argued that, because in contracts for workmanship and materials the courts often speak of an implied warranty of workmanship, ${ }^{102}$ when know-how or patents (1naterials) are combined with technical assistance (workmanship) in a single license whicli requires both to accomplisls the general purpose of the contract, a warranty should at-

156 See, e.g., Epstein v. Giannattasio, 25 Conn. Supp. 109, 197 A.2d 342 (C.P. 1963); Perlmutter v. Beth David Hosp., 308 N.Y. 100, 123 N.E.2d 792 (1954), noted in 31 IND. L.J. 367 (1956); cases cited notes 156-57 infra.

156 See, e.g., Albrecht v. Rubinstein, 135 Conn. 243, 63 A.2d 158 (1948); Walton v. Guthrie, 50 Tenn. App. 383, 362 S.W.2d 41 (1962); cases collected in Annot., 7 A.L.R.2d 1027, 1056-59 (1949); 1 S. Winuston, SALES \& 242(b); Prosser, The Implied Warranty of Merchantable Quality, 27 MINN. L. Rev. 117, 151-52 (1943); Note, 2 VaND. L. Rev. 675, 679-81 (1949); cf. Valeri v. Pullman Co., 218 F. 519 (S.D.N.Y. 1914).

157 See, e.g., Sloneker v. St. Joseph's Hosp., 233 F. Supp. 105 (D. Colo. 1964); Perlmutter v. Beth David Hosp., 308 N.Y. 100, 123 N.J.2d 792 (1954); Dibblee v. Dr. WH. Groves Latter-Day Saints Hosp., 12 Utah 2d 241, 364 P.2d 1085 (1961); see generally Note, 18 Okr. L. REv. 104 (1965); Note, 31 IND. L.J. 367 (1956).

158 See Cushing v. Rodman, 82 F.2d 864 (D.C. Cir. 1936); Levy v. Paul, 207 Va. 100, 147 S.E.2d 722 (1966); cases collected in Annot., 7 A.L.R.2d 1027, 1032-52 (1949); UnIfordar Commerctat Code § 2-314 \& Comment 5; W. Prosser, supra note 8, at 655.

159 See the review of cases in Sloneker v. St. Joseph's Hosp., 233 F. Supp. 105, 106-07 (D. Colo. 1964); Note, 18 OKLA. I. REv. 104 (1965); see also Epstein v. Giannattasio, 25 Conn. Supp. 109, 197 A.2d 342 (C.P. 1963) (lotion supplied in hair-dressing treatment not warranted since part of contract for services).

160 See Dibblee v. Dr. WH. Groves Latter-Day Saints Hosp., 12 Utah 2d 241, 364 P.2d 1085 (1961); Perlmutter v. Beth David Hosp., 308 N.Y. 100, 123 N.E.2d 792 (1954). 161 See cases and authorities cited note 158 supra. See also text accompanying note 164 infra.

162 E.g., Aced v. Hobbs-Sesack Plumbing Co., 55 Cal. 2d 573, 360 P.2d 897, 12 Cal. Rptr. 257 (1961) ; Kuitems v. Covell, 104 Cal. App. 2d 482, 231 P.2d 552 (1951); Mulhern v. Hederich, 430 P.2d 469 (Colo. 1967); Robertson Lumber Co. v. Stephen Farmers Co-op. Elevator Co., 274 Minn. 17, 143 N.W.2d 622 (1966). 
tach to the technical assistance provision which would guarantee that the experts and technicians would accomphish the hicensee's desired results. ${ }^{163}$ The foregoing argument should be rejected for the same cogent reasons that the doctrine of denying warranties of products in service contracts has generally been rejected. It is as capricious to attach warranty hability to one aspect of a contract merely because another aspect of the contract carries such assurances as it is to deny all warranties when only one aspect of the contract imports no such assurances. Pohicy dictates that services are not warranted, but that materials, goods and inventions are; consequently, hicenses should be viewed as divisible for warranty purposes. ${ }^{164}$

\section{VI}

\section{DAMAGES}

The damages for breach of warranty ${ }^{165}$ in a licensing agreement would generally be assessed under ordinary contract principles. A licensee could therefore recover the consideration he lias paid under the license, be relieved of paying any past or future royalties, ${ }^{168}$ and recover all foreseeable rehance expenses ${ }^{167}$ and any consequential losses, ${ }^{168}$ such as the reasonable costs of repairing hicensed property in an attempt to make it serviceable. ${ }^{169}$

However, a hicensee might have greater difficulty recovering lost profits. If the license is one to make a new product or to use a new process, it is

163 "[A]n action for breach of implied warranty will not lie where there has not been a sale of chattels but only the furnishing of services." Gautier v. General Tel. Co. 234 Cal. App. 2d 302, 306, 44 Cal. Rptr. 404, 407 (1965). It is possible however to interpret the construction contract cases as lolding only that the materials, and not the workmanship and labor, are impliedly warranted. In view of the general rule as to services, this would seem to be a more consistent interpretation. $C f$. J. Flearra, THE Law OF Torts 476-77 (3d ed. 1965). Moreover, most of the cases have involved defective materials rather than poor workmanship. See Aced v. Hobbs-Sesack Plumbing Co., 55 Cal. 2d 573, 583, 360 P.2d 897, 902, 12 Cal. Rptr. 257, 262 (1961). But see Kuitems v. Covell, 104 Cal. App. $2 \mathrm{~d} 482,231$ P.2d 552 (1951) (cited with approval in Aced v. Hobbs-Sesack Plumbing Co., supra at 582, 360 P.2d at 902, 12 Cal. Rptr. at 262).

164 Compare Note, 31 InD. L.J. 367, 373-76 (1956), suggesting that "some aspects of the service contract would seem to justify extension of warranty liability," depending on the "expectation of the parties." Id. at 374-75.

165 It should be noted that the theory upon which recovery is based will greatly affect the relief affordable. For example, innocent misrepresentation or mistake of fact would usually afford a licensee less relief than fraud or breach of warranty.

166 E.g., Nettograph Mach. Co. v. Brown, 28 Okla. 436, 114 P. 1102 (1911).

167 E.g., Tross v. H.E.G. Clarke Co., 274 Mich. 263, 265-66, 264 N.W. 365, 366 (1936); see UnIForm CoMmaractal Code $\$ \S 2-714(1), 2-715(1)$.

168 E.g., Himmelstein v. Budner, 93 F. Supp. 946 (D.D.C. 1950); Mack v. Hugh Comstock Assocs., 225 Cal. App. 2d 583, 37 Cal. Rptr. 466 (1964); In re Casualty Co., 250 N.X. 410, 165 N.E. 829 (1929); Craftsman Glass Inc. v. Cathey, 351 S.W.2d 950 (Tex. Civ. App. 1961); UNIFORM CoMnMERCTAL CoDE \& 2-715(2).

169 E.g., Standard Oil Co. v. Boyle, 231 App. Div. 101, 246 N.Y. Supp. 142 (1930); Nettograph Mach. Co. v. Brown, 28 Okla. 436, 114 P. 1102 (1911). 
doubtful that profits which the licensee contemplated from the new product or process would be awarded: They would be speculative and uncertain, whereas damages must be certain. ${ }^{170}$

Where a new business or enterprise is engaged in, and damages by way of profits are sought for its interruption or prevention, the rule is that they will be denied, for the reason that such business is an adventure as distinguished from an established business, and its profits are speculative and remote, existing only in anticipation. ${ }^{171}$

In general, as licenses are risky and as there is a consequent doubt as to whether a licensee has really lost profits, the courts are likely to exercise restraint to avoid recoveries which would place too great burdens on licensors. ${ }^{172}$

However, if a new business or enterprise is not involved, lost profits should be awarded in accordance with the ordinary principles of contract law. For example, $X$ hicenses $Y$ to use his patented process and secret information which, it is believed, will facilitate production of $Y$ 's product; $Y$ removes all of his machinery to install new machinery which is required for the new process; if the new process is not suited to manufacture $Y$ 's product, $Y$ could recover profits which he would have earned had he not had to remove and then replace his old machinery. ${ }^{173} Y^{\prime}$ 's past profit record would insure certainty in measuring lost profits and the fact that his product had been successful would vitiate any claim that profits were too speculative.

\section{CONCLUSIOIN}

Patent, know-how and technical assistance licenses are generally much more involved, complicated and important than sales contracts. Ideas, plans and inventions which allow a hicensee to produce an entirely new product might be mvolved. It can be argued that to imply warranties in such agreements is tantamount to the licensor's assuming the undesirable role of an insurer of the licensee's busmess success.

170 California Press Mfg. Co. v. Stafford Packing Co., 192 Cal. 479, 485, 221 P. 345, 347 (1923); see 5 A. Corban, Contracts \& 1023, at 150-51 \& n.96 (2d ed. 1964).

171 California Press Mfg. Co. v. Stafford Packing Co., 192 Cal. 479, 485, 221 P. 345, 347 (1923); accord, Alder v. Drudis, 30 Cal. 2d 372, 382, 182 P.2d 195, 201 (1947) (profits to be derived from new, patented device "probably too speculative and conjcctural"); Tross v. H.E.G. Clarke Co., 274 Mich. 263, 265-66, 264 N.W. 365, 366 (1936) (profits from exploitation of patented device "wholly speculative and unprovable"); see Annot., 99 A.L.R. 938 (1935); Annot., 1 A.L.R. 156 (1919); see generally 5 A. CoRBEN, sulpra note 170 , at $\S 1022$.

172 See G. Grusmore, Princtrles of the LaW of Contracts § 197, at 306 (J. Murray ed. 1965); $c f$. cases cited note 171 supra.

173 See Webster v. Beau, 77 Wash. 444, 137 P. 1013 (1914); 5 A. Corbav, stipra note 170, at $\S 1023$; cf. Himmelstein v. Budner, 93 F. Supp. 946 (DD.C. 1950); Mack v. Hugh Comstock Associates, 225 Cal. App. 2d 583, 37 Cal. Rptr. 466 (1964). 
Yet the very fact that licenses have so much commercial importance is good reason to insist upon integrity, ligh standards of quality and reasonable assurances that the parties' expectations will be fulfilled. Also, it should be made clear that to imply warranties in licenses does not nnake the licensor an insurer of the licensee's business success: The hicensor will be hable only when his patent or know-how is either not reasonably suited to the general uses for which it was developed or not suited to the known, particular purposes of the licensee who has justifiably rehed on the $h$ censor. Never will the hicensor be liable if the facts indicate that the licensee has assumed the risk that the patent or know-how might be unsuited to his purpose or generally worthless. Moreover, warranty liability for technical assistance is himited to situations in which the experts or technicians do not possess the skill and knowledge required of the work to be performed; otherwise, neghigent or intentional misconduct must be shown.

The licensor will generally have to be experienced with the unaterials hcensed for warranties to be inplied; if he is not, le will not qualify as a merchant or dealer for the warranty of merchantability and the licensee will probably not be justified in relying on him for the warranty of fitness for a particular purpose. Finally, the examination requirements might often negate all warranty liability. ${ }^{174}$ Generally, however, the experienced hcensor should be held to warranty liability when his unaterials prove to be worthless; he should also be lield if the inaterials are unsuited to the licensee's purpose when the latter has justifiably relied on the licensor to supply plans, an invention, technical assistance or information suited to that purpose.

\section{William T. Vukowich}

174 The simpler, more orthodox means of limiting and fixing the parties' liabilities is, of course, to provide for all contingencies in the license. See, e.g., Kraus v. General Motors Corp., 120 F.2d 109 (2d Cir. 1941); Holmes Packaging Mach. Corp. v. Bingham, 252 A.C.A. 926, 60 Cal. Rptr. 769 (1967); Untrorar Commerctar Code § 2-316(1)-(2); L. ECrstrom, supra note 135 , at IV. 